\title{
Everything is skimped now Food in war times through the eyes of women
}

\section{Marta Correia}

\author{
ILCML / CETAPS / University of Porto
}

\begin{abstract}
The aim of this paper is not to present critical dystopias as traditionally understood, views of a postapocalyptic future world where there is a glimmer of hope and a possibility of change amidst a seemingly irreversible chaos. Rather, I intend to consider representations of reality itself as dystopia through diaries, memoirs, reports or works of "faction" 1 written by women enduring or revisiting war times. Through the reading of these multiple texts, I hope to find common ground and identify the role food plays in the lives of people trying to cope with the inevitable scarcity of resources an armed conflict brings. I also attempt to determine whether there is a cultural ideal behind the everyday action that is the sharing of food and, thus, find in Utopian Foodways a tool of resistance which counteracts the fragmentation of society, but also a means to denounce and expose the hypocrisy of those who wage war.
\end{abstract}

Keywords: women's writings, dystopian reality, war, food, Utopian Foodways

Resumo: 0 objectivo deste artigo não é apresentar distopias críticas como entendidas tradicionalmente, visões de um futuro pós-apocalíptico onde existe uma possibilidade de mudança e um vislumbre de esperança no meio de um caos aparentemente irreversível. Em vez disso, pretendo considerar representações da realidade como distopia através de diários, memórias, relatos e narrativas ficcionais baseadas em histórias reais escritos por mulheres enquanto vivem ou revisitam tempos de guerra. Através da leitura destes textos, espero encontrar pontos em comum e identificar o papel da alimentação na vida das pessoas que tentam sobreviver com a inevitável escassez de recursos que um conflito armado causa. Tenciono também avaliar se 
existe um ideal cultural por detrás da partilha diária de alimentos e, assim, descobrir na Alimentopia, uma ferramenta de resistência que contraria a fragmentação da sociedade, e também uma forma de expôr e denunciar a hipocrisia daqueles que activamente originam guerras.

Palavras-chave: escrita de mulheres, realidade distópica, guerra, alimentação, Alimentopia

\section{Introduction}

This essay explores a selection of texts written by women of diverse backgrounds in different times of history affected, more or less directly, by an armed conflict. It was my aim to determine if what these women have to say about daily life in times of war had anything in common, in order to attribute possible symbolic roles to food. The polyphony of female voices composes the basis of some Utopian Foodways observed in times of scarcity. Upon reading these texts I was faced with similarities which equalised the disparate protagonists in the stories they told. These are not texts of fiction written intentionally as "oppositional thought with regard to the (...) historical situation" (Fortunati 2000: 141), nor are they literary "social projects of hope (...) which open a space of contestation and opposition" (Baccolini 2004: 521), or texts offering an alternative world with a "militant utopian stance" (Moylan/Baccolini 2007: 14). These are not, therefore, critical dystopias as traditionally understood in the field of Utopian Studies. Instead, they depict a dystopian reality, a bleak image of need and, all too often, desperation. In analysing these writings I set out to find

glimmers of hope and resistance in the relationship people establish with the little food available depicted in the testimonies collected, i.e., examples of Utopian Foodways.

As a framework for this study, I will use Maslow's Hierarchy of Needs (1943), which ranks human needs by categorising them in order of urgency. According to this theoretical tool, one can only satisfy one's highest needs if the basic ones have been met. As such, one will only pursue Psychological needs once the Basic needs have been met. Similarly, Selffulfillment needs will be procured only when the Basic and the Psychological needs have 
been attained. I would argue that in times of war one is imprisoned in the most basic of tiers, the Physiological needs, which includes food. Even the second sub-tier is relegated, since security and safety might be mere illusion or simply unobtainable. The voices we hear are under attack, a status which locks them in the very first and primary level of existence, i.e., subsistence.

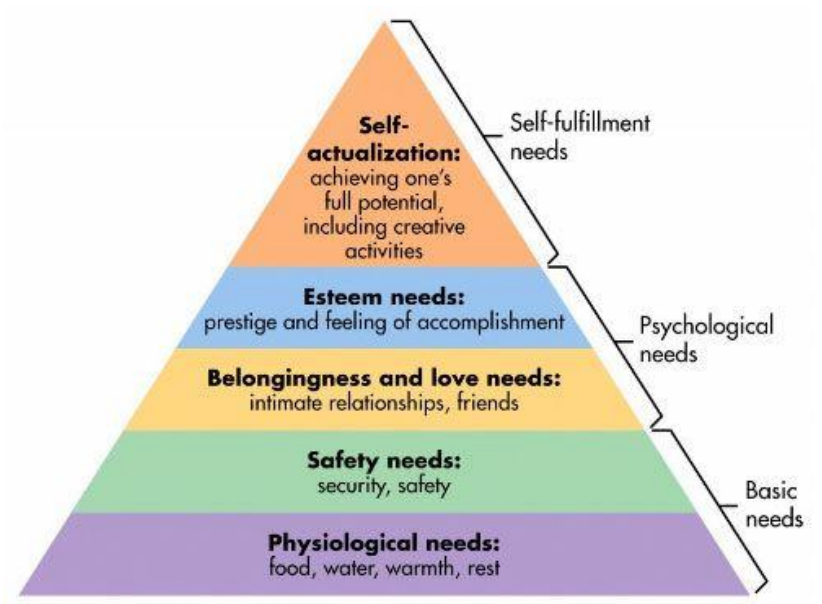

Fig.1 Maslow hierarchy of needs ${ }^{2}$

I saw my mother weeping

While she was preparing dinner

What has made you cry, Mother?

You say it's the onion

But there is no onion

in your hands...

Maram al-Masri, Syrian poet, 2015

\section{Dystopian reality}

When Virginia Woolf wrote the words that give the title to this essay in January 1918, World War I was raging in Europe and food was inevitably rationed. Her diary reveals 
how the war interfered with her daily mundane life. The food shortages are a constant reference: "I counted my lumps of sugar, 31"; "Everything is skimped now"; "The bakers windows now provide almost nothing but little plates of dull biscuits; sections of plain cake; \& little buns without any plums. If you see a plum, it is invariably a decoy plum; there are no others" (Woolf 1977: 81, 100, 112). Food is counted, rationed, the dishes in the bakery are small as are the buns, dull, plain, bland buns and the fruit, should you see any, is make believe.

Years later, Samar Yazbek, a Syrian dissident living in exile in Paris, describes in her book of reports The Crossing published in 2015, the struggle of her countrymen and women. She writes, "they had no space to think. The details that concerned them were whether they would be able to get hold of any flour to make bread. Coffee was a commodity rarely to be found; would they even find any tea or sugar? (...) Was one meal going to be enough to feed several mouths? Would any of them reach the end of their natural lifespan?" (Yazbek 2015: 132). How can there be time to think? They are trapped in the most basic of tiers of the Maslow Hierarchy of Needs and, as such, have no mental room for anything other than survival. Their days are spent thinking about what they can eat, looking for food or trying to buy it in dire circumstances.

Water containers and markets are common targets of armed groups who are looking to cripple whole populations to win a war. The first big massacre in the Bosnian capital city in the 1990s is noted by Atka in the book of memoirs written by two sisters, Goodbye Sarajevo: "at the end of May, when a Serb shell killed twenty-people queuing for bread" (Reid / Scofield 2011:24); in Syria people "might be killed for the sake of buying three loaves of bread" (Yazbek 2015:202). Starvation is a powerful and effective weapon of war widely used throughout history. If you want to break a community, take their food away as, without it, people will not survive. Symbolically, targeting civilians trying to buy the most basic of food items, such as bread, ${ }^{3}$ is a means of denying them life, not only through military obliteration, but also by turning the vital act of buying food into a dangerous activity. Fear adds to the difficulty of obtaining food and, thus, terrorises those who must venture out in search of sheer survival for themselves and their families. 
Buying food is, under fire, life-threatening, but also a forced luxury. The Black Market thrives in conditions like these. In Goodbye Sarajevo Atka notes, "the few vegetables and canned food that were available now cost twenty times more than before the war" (Reid / Scofield 2011:53); Anne Frank also refers to the immoral prices in her diary: "Jews in hiding like us (...) can only afford to buy four rather than eight ration books on the black market (...) the papers write every evening in big, fat letters: 'Play fair and keep Prices Down'!" (Frank 2002:78). The matriarch in charge of the part of the family who stays in the Bosnian capital in Goodbye Sarajevo trades gold for food: "on the black market for two large sacks of rice and flour, a can of oil, some canned food and a packet of candles" (Reid/ Scofield 2011:30).

Preparing the little food you manage to buy or find is also a challenge as inevitably there are power cuts and no running water. Zlata Filipović, a young girl who kept a diary as she was growing up in besieged Sarajevo notes that her city has no parks left: "The winter and the power cuts have condemned the old trees, arboured walks and parks that made Sarajevo so pretty" (Filipović 1995: 96). Everything is consumed, including the city itself, as trees are used for heating and cooking. The same happens in Syria: "The Roman site was surrounded by olive groves, but many of the trees had been cut down or burnt" (Yazbek 2015:66). Trees, clothes, furniture, even books are burnt. Anything that can burn, will burn. In Goodbye Sarajevo people share tips for survival: "Is your grandma using doors for firewood? (...) I've heard that leather shoes and jeans burn well too"'; "The hard covers of Das Kapital were so slow burning, I managed to bake a whole loaf of bread (...) Lenin burns well too" (Reid / Scofield 2011: 56, 81, 82). As the hegemonic ideology shifts, and its books burn, Yugoslavia is reduced to ashes.

Cooking is an activity traditionally ascribed to women and can be a tool to express power. Women prepare the food that feeds the family and could either produce tasty meals as a means of reward or inedible, and even poisoned dishes, in order to assert their control over the family (Sceats 2003: 142). Their diminished power caused by the lack of ingredients, electricity and water cuts leads to the inability to cook what they or their families want/need. They have to submit to the limitations of the very little that is available. 
Nevertheless, the matriarch in Goodbye Sarajevo manages to retain some form of power over food using what I would call imaginative cooking: "Food was scarce but Grandma picked stinging nettles and dandelions from our back garden and taught me how to make a pie and a salad with them" (Reid / Scofield 2011: 36). By using unexpected items, the grandmother succeeds in producing a meal, which, under siege, is an achievement in itself. Though lacking in nutritious benefits, the pie and salad are served and eaten by the family living under extreme scarcity, enabling them to maintain a certain, if elusive, level of normality.

The deficient diet during an armed conflict brings serious consequences. The physical evidence of it is constantly referred to and described in Goodbye Sarajevo: "Some days there was nothing to eat and we were weak with hunger. The children were malnourished and their teeth were decaying. Tarik's long blond hair had starting falling out in clumps"; "the boys were very skinny and weren't growing much" (idem: 87, 139). Maternal feeding effectiveness is also curtailed by the poor diet that can be offered. When everything is skimped, there is no variety. The eldest daughter in the family in Goodbye Sarajevo reports they "had been eating rice for weeks. Just looking at it made me feel sick" (ibidem: 25). Anne Frank complains: “We've eaten so many (...) beans that I can't stand to look at them"; "For the last two weeks lunch has been either spinach or cooked lettuce with huge potatoes that have a rotten, sweetish taste" (Frank 2002: 88, 98). Anne describes the eating routines in the Annexe: "A food cycle is a period in which we have only one particular dish or type of vegetable to eat. For a long time we ate nothing but endive with mashed potatoes (...) Then it was spinach, followed by kohlrabi, salsify, cucumbers, tomatoes, sauerkraut, etc., etc."; "Vegetables are hard to come by. There's only lettuce, lettuce and more lettuce. Our meals consist entirely of potatoes and imitation gravy"; "This afternoon we had rotten boiled lettuce." (idem: 248, 265, 280).

In Sarajevo, a young woman, fulfilling her nurturing role in the absence of her mother, ${ }^{4}$ tries to make her little brothers cope with the limiting diet by producing makebelieve meat out of rice: "I shaped some of the rice into small balls and put them on a separate plate. The boys, excited at the thought of eating meat again, were drumming their 
feet under the table" (Reid / Scofield 2011:31). In this scene we can observe a surrogate mother who is far too young to be left in charge of two young children in such severe circumstances. Also, and adding to the layers of meaning and suffering, the children are far too young to know the difference between decoy meat and rice. These children are the ones who, upon receiving some oranges as a gift from their family living in exile in Croatia, did not even know what oranges were. But still families endure and survive, the ultimate act of resistance - not to be eliminated by arms or hunger.

A sign of hope flourishes in Sarajevo, where everything else is dying. A plum tree bears fruit in the family garden, and no, they are not decoy plums. The eldest daughter turned into mother narrates the thrill of having access to fresh fruit: "It was an exciting addition to our bland and relentless diet of rice and flour" (Reid / Scofield 2011:52). Sadly but perhaps inevitably, like every other tree in Sarajevo, the generous plum tree is cut down by two intruders who would certainly have their own stories of deprivation.

The lack of food, recognised as poverty, is perceived as a lack of dignity. Formerly well-to-do families have to resort to begging. In Syria, Yazbek reports: "What hurts most is the broken look in my dad's eyes, the look of humiliation, and the expressions of gratitude he repeats to everyone who offers us food and bread. We used to live comfortably and had everything we needed, and now we are living on charity and handouts" (Yazbek 2015: 60). As a refugee in Croatia Hana resorts to charities as well: "There's not much food left (...) We'll have to go to the Red Cross (...) to collect some" (Reid / Scofield 2011: 110); and in Bosnia scenes of desperation are witnessed when "Men, women and even small children ran frantically to the forest when the parachutes landed, scrambling to grab whatever food they could find" (idem: 308). Zlata complains that "This isn't life, it's an imitation of life" (Filipović 1995: 78). Life as decoy plums, as make believe meat - not real life or what life should be like. 


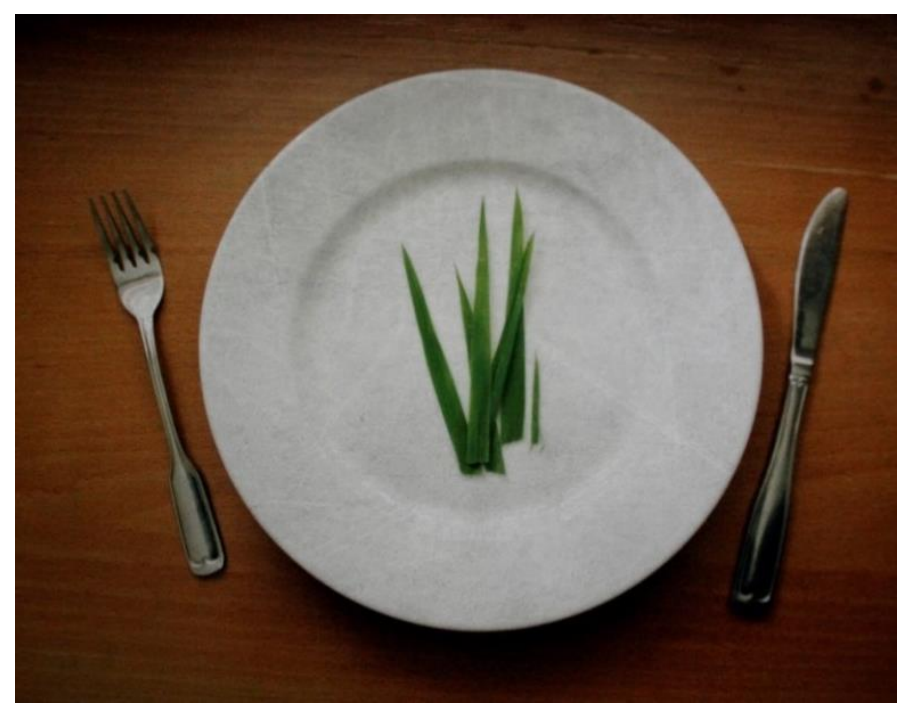

Fig.2 Hunger (C) 2016 Moustafa Jano 5

Under such conditions, womens' bodies are also used as currency to obtain food. Yazbek comments on the fact that families are marrying daughters off in Syria "as a means of overcoming poverty and hunger" (Yazbek 2015: 122) and Anne Frank notes that "Everyone wants to put food in their stomachs, and since wages have been frozen, people have had to resort to swindling (...) many girls (...) are reported missing every day." (Frank 2002: 283). A Woman in Berlin, a diary written anonymously at the end of World War II when the Russian troops arrive in the capital, reveals the ordeal of a non-allied woman and what she has to do to survive: "I'm living well here. No more nettles; now there's meat, bacon, butter, peas, onions, canned vegetables"; "As a rule [Russian soldiers] look for a more permanent arrangement, something exclusive, and they're prepared to pay. They've realised how badly off we are when it comes to food" (Anonymous 2011: 107, 108). In such extreme circumstances, this woman is forced to trade her body for food. Her life becomes possible due to the domestic arrangements with the Russian major who brings her staple and even tasty nourishment in exchange for the sexual use of her body. She sees herself as a prostitute and claims "I can't complain (...) By no means could it be said that the major is raping me (...) I should now call myself a whore, since I am living off my body" (idem: 139, $140,141)$. She does what she has to do under the impossible state of affairs she is 
confronted with, but still she challenges her own actions in such an amoral framework. It is as if she accepts her condition as a woman on the losing side of the war, who, for both reasons, deserves the humiliation she is subjected to. No Russian soldier questions his right to the body of a woman. The intersection of these two elements, the fact this is the body of a woman and that this body is on the enemy's side, worsens the situation as it removes the Other twice. Alterity reduces a person to an Other, not worthy of respect or dignity. Double alterity justifies any action in the eyes of the perpetrator, and, it seems, victim alike.

As If I Am not There written by Slavenka Drakulić, a now Croatian writer, follows the life of S., a young woman of mixed origins, Bosniak and Serb, who finds herself in a concentration camp at the end of the $20^{\text {th }}$ century when the conflict in the former Yugoslavia is raging and where women are repeatedly gang raped by Serb soldiers. S. becomes the camp's captain private sexual slave, although this status was never a choice of her own. This new rank gives her access to decent dinners, wine, coffee, sitting on a sofa, bathing in hot water and sleeping in clean sheets. As a regular prisoner in the camp she would have access to none of these things, but would still be subject to sexual attacks. S. feels grateful for this and questions her role in the camp, although she occasionally contemplates killing her aggressor: "she is the only real prostitute among them, and that's how she feels (...) Is she still a victim like the others?" (Drakulić 2012: 116, 117). Women whose bodies, through no choice of their own, are used in exchange for survival, question their own morals, and do what is demanded of them.

\section{Utopian Foodways}

In Sarajevo, Zlata's words explore how life has changed since the war started, how much she misses fruit and how food has become such an important part of life. Arriving back home from Paris where she presented her book, Zlata reports having received a lovely welcoming present: "When I got home that afternoon, Auntie Radmila brought me a big flowerpot wrapped in colourful paper and tied up with a bow. Inside the pot was a tomato, a real live tomato. That was the nicest 'bouquet' I ever got" (Filipović 1995: 154). Within restricted environments where subsistence becomes the only focus, food is used as an 
offering on special occasions which cannot but be marked over the years even in a city under siege or occupation. In Anne Frank's diary her parents' birthday presents are noted: "For Mother's birthday, she received a real mocha cake, pre-war quality"; "Yesterday was Father's birthday (...) [he] received a huge box (...) containing 3 eggs, a bottle of beer, a pot of yoghurt and a green tie" (Frank 2002: 170, 295). For Anne's own 15th birthday she received two pots of yoghurt, a pot of jam, two honey biscuits (small) and sweets, amongst other knick-knacks (idem: 313, 314). In war times, food, whatever food can be spared, becomes a gift, and celebrations of special occasions do not go unnoticed; people still gather around the table and make an effort to transform the long days of life under attack into special, intimate and memorable moments.

Among these bleak images of desperate need, we find episodes of hope, of sharing. Food is quite commonly used as a sign of hospitality. Yazbek reflects on the host families who make her crossings from exile back to Syria possible: "The moment we arrived everyone was mobilized into preparing dinner for us"; "His wife invited us to eat with the family (...) There was no water and the electricity had been cut off but they treated us to an abundant spread. In fact, everywhere we found ourselves as guests, our hosts would go out of their way to offer the best hospitality they could. I was sure the food was often all they had, and yet there was no hesitation; it was put on the table" (Yazbek 2015: 7, 70). The matriarch in Goodbye Sarajevo uses her imaginative cooking and prepares a nettles pie to receive a foreign guest at her home (Reid / Scofield 2011:115). No matter how little people have, their culture and their manners dictate that food is for sharing. Amidst the fragmentation of reality, food, as an essentially social signifier, and a fundamental interpersonal and social act, as Sarah Sceats contends (2003: 125), is used to maintain the (possible) level of normality. Sharing a meal, even if it is a rotten meal, can be seen as a way to insist on a sense of community and resist complete disintegration. Through eating together, one can maintain a social and cultural thread that keeps people united, a ritual that binds people together...and maintains life. There are also examples of planned resistance. The women's Grocery Store project in Saraqeb mentioned in Yazbek's work is an example of how the civilian population and NGOs can organise themselves to allow access 
to employment, affordable food, and other essential items in contemporary Syria (Yazbek 2015:172). 6

Surprisingly, in her reports collected in They Would Never Hurt a Fly, Slavenka Drakulić identifies a legally-imposed micro-society of indicted war criminals from all countries of the former Yugoslavia. The detention unit for indicted war criminals in the International Tribunal for the Former Yugoslavia in The Netherlands is a space outside the territories of the Western Balkans, and in every way different to the atmosphere experienced in that region but inhabited by the very same men who caused the unbreathable air of compulsive alterity. ${ }^{7}$ The detainees from all parts of the collapsed country, arch-enemies judging by the rhetoric they themselves imposed, or helped impose, on their peoples, read the same newspapers, play sports and games side by side and perfectly understand each other regardless of whether they speak Serbian, Croatian or Bosnian. They compromise, are civil and reveal solidarity towards each other. It looks like, Drakulić adds, "little Yugoslavia". In this community, food is also an element of union and indispensable in the marking of special occasions. They celebrate Catholic and Orthodox Christmas and Muslim holidays as well and they are allowed a whole piglet to roast as if they were at home, the old home of "Brotherhood and Unity", 8 not the burning home of hatred they left behind. Celebrations take place around the table, like anywhere in the world even in times of war, and these men "are not nationalists when it comes to good food (...) they eat together, enjoying every morsel of it" (Drakulić 2013: 174). These are the men responsible for the worst conflict Europe had seen since the Second World War and, yet, they live in harmony, having preached irreconcilable differences between the peoples of the former Yugoslavia. The dystopian nightmare they created gives way to a utopian reality within their reach. And if they can do it, no doubt, so can anyone else.

\section{Conclusion}

As the ultimate equaliser, food can be used to foster cooperation and solidarity, even among those who claim such a scenario is unattainable and/or undesirable. Sceats contends that "Food is a weapon, but also a means of communication" (2003: 112), and whether we 
choose to use it as one or another, depends solely on ourselves. Sometimes the only choice we have is to create the food that does not exist to feed ourselves and each other. We use food as a gift or to show hospitality and even as an act of resistance to stay alive against all odds by resorting to schemes, imagination or whatever is necessary. The scene in the detention centre in The Hague shows us a utopian possibility of togetherness where peaceful cohabitation is possible even amongst those who preach otherwise. Professional ethnonationalists, too, succumb to the communal way of living that the population in the former Yugoslavia were denied and encouraged to reject. They too share celebrations and food, thus displaying the hypocrisy of the criminal regimes they led. Detained under international jurisdiction, they organise their existence so that they can bear it, perhaps not aware of the cruel irony involved.

People from different eras, backgrounds and parts of the world seem to find similar Utopian Foodways to deal with the fragmentation of their reality. Regardless of where we are, who we are or what time in history we live in, regardless of our religion, colour or personality, we share the same problems, needs and aspirations; the Maslow's Hierarchy of Needs applies to all of us and that is a clear sign of our sameness. 


\section{NOTES}

${ }^{1}$ Slavenka Drakulić defines "faction" as a combination between facts and fiction, a genre she used in As If I Was Not There: "I thought that I would attempt to articulate what the women had felt in another way, using literary means (...). In the book all the factual details are true. This is called faction (...) the books of documents that were published (...) are unbearable to read." Berlin Interviews March 2014 $<$ http://berlininterviews.com/?p=1074> (last access 20/02/2017)

$2<$ http://www.simplypsychology.org/maslow.html> (last access 20/02/2017)

3 The symbolic meaning of bread is captured as Sarah Sceats notes in the meaning of the word "companion", which combines the Latin words com (with) and panis (bread) (2003:132). A staple item made for sharing, itself a symbol of the survival of the community.

${ }^{4}$ The mother figure in Goodbye Sarajevo is absent, as she decided to assist refugees from the war and work with NGOs. The maternal figure in the household in the Bosnian capital is delegated to the grandmother primarily but also to the daughter, who takes on the role in co-mothering her younger siblings.

${ }^{5}$ Moustafa Jano is a Syrian artist from Aleppo currently living in exile in Sweden and awaiting to be reunited with his family. He constantly produces work related to the human catastrophe in Syria.

${ }^{6}$ The NGO Women Now runs three grocery stores, a bakery and a workshop for fermenting yogurt in Saraqeb in Syria at the time of writing. By organizing these projects, women find support to feed their families, but also a sense of community and purpose. In a patriarchal society, at times of war, able men are either away fighting or have been killed. Women are left to secure families as best they can. <http://www.womennow.org/project/saraqeb-widows/> (last access 20/02/2017)

7 I define compulsive alterity as the state-promoted rhetoric which focuses on the national origins of a group to produce otherness, creating a sense of "natural" right to belong to a certain land, and, by implication, a "natural" alien-status for those who do not fit the requirements by reasons of lineage. Although not a unique case in history, compulsive alterity was used as a weapon of war throughout the former Yugoslavia at the end of the $20^{\text {th }}$ century.

8 "Brotherhood and Unity" was a slogan used during Tito's rule of Yugoslavia, where nationalistic inclinations were repressed, and the various peoples encouraged to live together and cooperate with each other. 


\section{Works Cited}

Anonymous (2011), A Woman in Berlin - Diary 20 April 1945 to 22 June 1945, translated by Philip Boehm, London, Virago Press.

Baccolini, Raffaella The Persistence of Hope in Dystopian Science Fiction in PMLA, Vol.119, №3 Modern Language Association, 2004, pp. 518-521.

Drakulić, Slavenka (2012), As If I Am Not There, translated by Marko Ivić, London, Abacus [1999].

-- (2013), They Would Never Hurt a Fly, London, Abacus.

Filipović, Zlata (1996), Zlata's Diary, translated by Christina Guru-Murthy, London, Puffin Books.

Fortunati, Vita/Raymond Trousson (eds) (2000), Dictionary of Literary Utopias, Paris, Editions Champion.

Frank, Anne (2002), The Diary of a Young Girl, translated by Susan Masotty, edited by Otto H. Frank and Mirjam Pressler, London, Puffin Books.

Moylan, Tom/Raffaella Baccolini (eds) (2007), Utopia Method Vision - The Use Value of Social Dreaming, Bern, Peter Lang.

Reid, Atka / Hana Scofield (2011), Goodbye Sarajevo, London, Bloomsbury Publishing.

Sceats, Sara (2003), Food Consumption and the Body in Contemporary Women's Fiction, Cambridge, Cambridge University Press.

Woolf, Virginia (1977), The Diary of Virginia Woolf 1915-1919, Anne Olivier Bell edition, Volume I, London, Harcourt Inc.

Yazbek, Samar (2015), The Crossing - My Journey to the Heart of Shattered Syria, translated by Nasha Gowanlock and Ruth Ahmedzai Kemp, London, Rider. 
Marta Correia is currently attending a PhD course in Feminist Studies at the Faculty of Arts and Humanities at the University of Porto. She holds an M.A. degree in Women's Studies. Her main interests in research include Virginia Woolf and her facet as a feminist, women's activist groups, female writers who focus on the issues of oppression and war, and also food in times of armed conflict through the eyes of women writers. At the moment, she is researching the work of Slavenka Drakulić, a Croatian author who has dedicated some of her writings to the conflict in the former Yugoslavia. Marta has participated in a number of projects at the University of Porto coordinated by CETAPS (the Centre for English, Translation and Anglo-Portuguese Studies) and ILC-ML (Instituto de Literatura Comparada Margarida Losa), and several international conferences in Portugal and abroad. 